\title{
Effect of Reactant Gas Flow Orientation on the Current and Temperature Distribution in Self-Heating Polymer Electrolyte Fuel Cells
}

\author{
L. Rasha ${ }^{1}$, J.I.S. Cho ${ }^{1}$, J. Millichamp ${ }^{1}$, T.P. Neville ${ }^{1}$, P.R. Shearing ${ }^{1}$, and D.J.L. Brett ${ }^{1 *}$ \\ ${ }^{1}$ Electrochemical Innovation Lab, Department of Chemical Engineering, UCL, London, UK, WC1E 7JE
}

\begin{abstract}
${ }^{*}$ Author to whom correspondence should be addressed
Tel.: $+44(0) 2076793310$

Web: https://www.ucl.ac.uk/electrochemical-innovation-lab

Email: d.brett@ucl.ac.uk
\end{abstract}

\begin{abstract}
Fuel cell polarisation performance is typically reported under controlled / constant temperature conditions, as a sign of robust metrology. However, in practice, fuel cells self-heat as they generate current; which varies the temperature across the polarisation curve and affects performance. More detail regarding the internal cell operation can be gleaned by current and temperature distribution mapping. For the case of an unheated cell, 'self-heating' increases the cell temperature and improves performance, resulting in a 'voltage recovery' and a more homogeneous current and water distribution. For actively heated cells, a reduced current is observed in regions of high temperature and low humidity.

The positioning of the gas manifolds also has a decisive impact on performance by affecting the reactant concentration, humidity and water distribution. Counter- and cross-flow orientations in a self-heating cell were studied, with a counter-flow orientation with air flowing with gravity producing the most uniform temperature distribution.
\end{abstract}

\section{Keywords}

Self-heating; Non-isothermal; Voltage recovery; Current distribution mapping; Temperature distribution mapping; Flow orientation. 


\section{Introduction}

It is customary to report fuel cell polarisation performance quoted at a constant temperature across the range of operation and with each data point recorded after the system has had time to equilibrate. This requires an active heating / cooling system and extended periods of data collection, but does not capture the intrinsic operation of a stand-alone fuel cell. It is questionable if robust temperature control is always implemented effectively in reported studies, and in any case, there is likely to be a distribution of current density and temperature within cells such that true isothermal operation is exceedingly difficult to achieve. In practice, for technological systems, fuel cell temperature will vary across the polarisation curve range [1-4] when exposed to dynamic operation and during start-up [5]. Temperature will be heterogeneously distributed across cells and throughout stacks and is a complex function of reactant flow [6], current density distribution [7, 8], flow-field design [9, 10], cooling mechanism $[11,12]$, etc. Depending on the size of the fuel cell, its application and core design principle, technological fuel cells may have active heating during start-up, be air or liquid cooled, or have no active cooling / heating at all [13-15]. As such, in addition to the conventional controlled temperature approach, studies should take account of the fact that fuel cells do not operate isothermally and consider the polarisation curve where self-heating takes place during operation. In addition, some fuel cell 'start-up from cold' strategies drive the devices hard in order to generate heat and raise the temperature [16]. Therefore, self-heating polarisation curves are an important phenomenon to capture, with heterogeneities possibly leading to accelerated performance degradation $[17,18]$ and the results obtained will be sensitive to the size of the cell / stack, design and flow orientation.

In practice, polarisation curves are often achieved that deviate from the 'classic' sigmoidal profile (kinetic, Ohmic, mass transport). To understand the cause, advanced characterisation should be performed on systems that are not artificially constrained in temperature, as this is often the cause of these effects. Temperature affects the electrode kinetics, electrolyte conductivity, mass transport of species and is particularly impactful on water management within fuel cells [19].

While the polarisation curve is the key measure of fuel cell performance and is the ultimate test of what a fuel cell can deliver in terms of electrical output, the information it provides is limited in terms of truly understanding the internal operation of the device. Current and temperature mapping of polymer electrolyte fuel cells (PEFCs) uncovers crucial spatial and temporal data on the performance distribution across its active area. Achieving a homogeneous current density distribution during operation is desirable, which corresponds or 
is a consequence of its thermal uniformity $[20,21]$. However, local performance disparity is common due to operational conditions, such as reactant concentration, humidification and water distribution [22-24]. This problem is exacerbated during scale-up, advancing from small lab-scale single cells to large commercial automotive stacks, where operational heterogeneities encourage large current density and temperature variations, resulting in varied local degradation rates and inefficient PEFC performance.

One particular design factor concerns reactant gas flow to the cell. The effects of flow-field plate design and gas flow direction on performance have been extensively researched using a variety of diagnostic techniques. Parallel, interdigitated, single- and multi-channel serpentine configurations are the most commonly implemented flow-field designs [25-27]. However, they are susceptible to localised flooding at higher current densities or at low temperatures, primarily in regions of significant pressure drop, which hinders reactant transport to the electrodes [28-31] and can cause irreversible damage by locally reversing the polarity in the gas-starved region [32]. This has catalysed research in innovative flow-field design focused on improving water, flow and pressure distributions [33-35]. Flow orientations have also attracted a great deal of research, predominantly in modelling [36, 37], where the direction of gas flow on either side of the membrane electrode assembly (MEA) affects the reactant and water distribution.

Water that is produced by the electrochemical reaction and introduced into the cell through gas humidification plays an important part in determining fuel cell performance. Liquid water can form and detach from the gas diffusion layer (GDL), coalesce and form slugs which flood the flow channels and limit mass transport [38]. Water detachment and removal is affected by gravity and numerous studies have found that gas flow from top to bottom greatly improves performance in both reactant compartments $[39,40]$. Conversely, studies on flow arrangement have found that counter- and cross-flows promote a more uniform current density distribution compared to co-flow configurations, by improving both the thermal and water management across the entire cell [41-44]. This would then require an upward gas flow against gravity in one of the flow-fields.

The effect of flow orientation on the PEFC water distribution was investigated by Kim et al. using a $25 \mathrm{~cm}^{2}$ cell with a 3-parallel serpentine design [45]. Water distributions were increasingly skewed along the flow channels towards the outlets, with greater non-uniformity in co-flow (outlets in same position). The effects of gravity were not considered in their study; however, studies by Morin et al. utilising small angle neutron scattering found that gravity retains water in the cell when the gas is flowing upwards, which leads to better membrane 
humidification [46]. A study by Wu et al., using an unheated $25 \mathrm{~cm}^{2}$ cell with no active reactant humidification, revealed that the water management is significantly affected by the number of serpentine channels at the cathode [29]. Single-channel serpentine designs exhibited the best performance and water distribution uniformity; however, they require a much higher parasitic power to recirculate reactants due to significant pressure drops in the flow-field. Severe flooding was observed in the quad-channel serpentines which resulted in large voltage fluctuations. Water accumulation was seen in the $180^{\circ}$ bends, skewed towards the cathode outlet and for quad-channel designs, predominantly in the final bends. With increasing current density above $400 \mathrm{~mA} \mathrm{~cm}^{-2}$, the total quantity of liquid water decreased by up to $43 \%$ as the effects of self-heating had dried the cell.

Current distribution mapping investigations of PEFCs are abundant in the literature [47, 48], but their coupling with internal thermal mapping is deficient. Common observations include a decline in performance downstream in the flow-field attributed to reactant concentration reduction [5, 49], reduced local membrane humidity [50] and gas starvation from flooding [51, 52], in addition to lower local currents around the $180^{\circ}$ bends compared to straight channels due to trapped water [53]. These results are dependent on operating current density, fuel cell design and operational parameters, which vary between applications. Combined current density and thermal mapping has been applied to the central cell of an open-cathode, aircooled, 5-cell stack [20]. The cross-flow configuration produced high current density results at the intersection of both inlets with a gradual drop towards the outlets. The temperature distributions followed the current density profile, relating to heat generation, except at the inlets where colder dry gas was introduced. Current and temperature mapping has also been applied to a $250 \mathrm{~cm}^{2}, 3 \mathrm{~kW}$ closed cathode stack operated with a cooling system [54]. Current distribution improved with increasing clamping pressure, with high currents passing through areas with greater contact pressure. Current density distributions were more sensitive to air flow rate than hydrogen and the configuration of air-coolant-hydrogen in co- and counter-flow created pocketed areas of high temperature and low humidity.

Whilst such studies have provided great insight and improved fuel cell design, they have predominantly focused on operation under controlled temperature conditions. There is an acute lack of insight into the operation of thermally unconstrained (self-heating) fuel cells. This work considers the performance of PEFCs without active heating / cooling and examines the 'self-heating' effect on the polarisation curve for different flow orientations. Localised measurements of current density and temperature are used to map the internal performance, quantifying the extent of heterogeneity across the MEA which could ultimately lead to increased degradation rates during long-term operation. 


\section{Experimental and Methodology}

\subsection{Fuel Cell Assembly}

The PEFC in Figure 1 was built in-house with a square active area of $100 \mathrm{~cm}^{2}$. Serpentine flow-fields with 7-channels and 6-bends were machined into $6 \mathrm{~mm}$ graphite plates, with a land width and channel depth and width of $1 \mathrm{~mm}$. Flow distribution was in a U-type pattern. Current collectors were made from copper plates that were gold coated for corrosion resistance. EPDM gaskets of $1.2 \mathrm{~mm}$ thickness ensured gas-tight operation and a suitable compression of the MEA. Endplates of $25 \mathrm{~mm}$ thickness were constructed from aluminium and anodised for electrical insulation. Silicon gasket sheets electrically isolated the endplate from the current collectors. The compression bolts were covered in an isolating sheath to prevent shorting between flow plates. The MEA consisted of a $15 \mu \mathrm{m}$ membrane (M820.15, GORE) and two $230 \mu \mathrm{m}$ GDLs (Freudenberg H23C9) with $0.4 \mathrm{mg} \mathrm{cm}^{-2}$ platinum loadings (HyPlat) placed on either side of the membrane. The MEA was then assembled together and hot-pressed for 3 minutes at $150{ }^{\circ} \mathrm{C}$ with a compression of $2.75 \mathrm{MPa}$ (Carver $4122 \mathrm{CE}$ ). The cell was torqued to achieve an MEA compression of $0.5 \mathrm{MPa}$, calibrated using pressure mapping (I-Scan, Tekscan). To condition the MEA, humidified reactant gases were fed to the system at $30{ }^{\circ} \mathrm{C}$ and with no external heating applied to the PEFC. The current density was incrementally ramped up to $1 \mathrm{~A} \mathrm{~cm}^{-2}$ and held for $15 \mathrm{~min}$. 10 voltage sweeps were performed between 0.8 to $0.5 \mathrm{~V}$ at $0.05 \mathrm{~V}$ increments for $60 \mathrm{~s}$ each. 


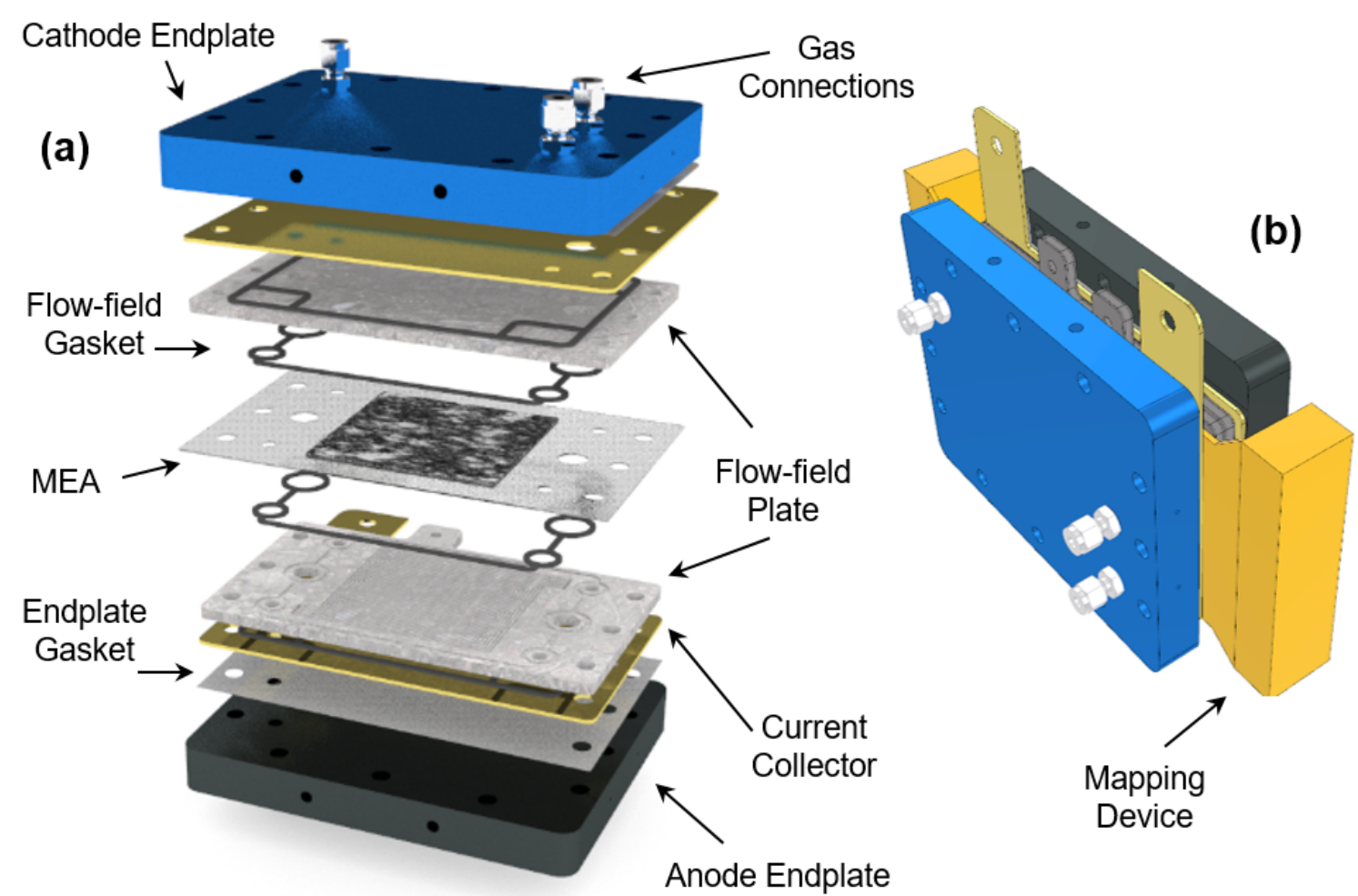

(c)

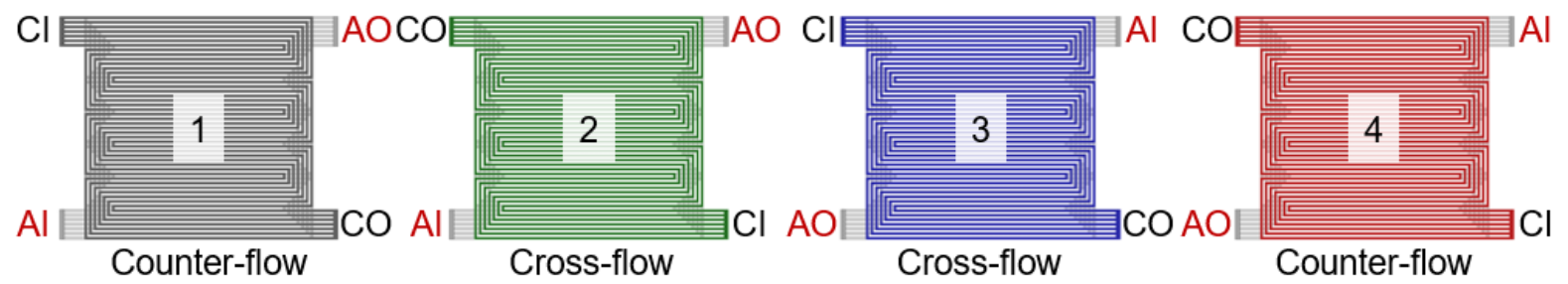

Figure 1 - (a) Exploded drawing of the $100 \mathrm{~cm}^{2}$ PEFC; (b) placement of the current and temperature mapping device at the cathode; (c) the four flow configurations with labelled cathode inlet $(\mathrm{Cl})$ and outlet $(\mathrm{CO})$ and anode inlet $(\mathrm{Al})$ and outlet $(\mathrm{AO})$.

\subsection{Fuel Cell Testing}

The experimental setup was controlled through LabVIEW (National Instruments) at a recording rate of $500 \mathrm{~ms}$. The anode inlet gas line was humidified by the bubbling method, with the water bath set to $30^{\circ} \mathrm{C}$. No cell heating was imposed in order to see the effects of a temperature distribution on cell performance. Zero grade gases were supplied by $\mathrm{BOC}$ (London, UK) with the following specifications: air (99.998\% purity) and hydrogen $(99.995 \%$ purity). A minimum flow rate of $0.2 \mathrm{~L} \mathrm{~min}^{-1}$ was set for both anode and cathode, with stoichiometric ratios of 1.5 and 3 , respectively. The polarisation curve was performed in 50 
$\mathrm{mA} \mathrm{cm}$ increments for $150 \mathrm{~s}$ up to $1300 \mathrm{~mA} \mathrm{~cm}^{-2}$ and terminated if the voltage dropped to 0 $\mathrm{V}$.

The current and temperature was mapped across the $100 \mathrm{~cm}^{2}$ active area using a PCB board mounted with a $14 \times 14$ array of shunt resistors and $7 \times 7$ temperature measurement cells with each current contact segment having an area of $50.5 \mathrm{~mm}^{2}$ (S++ Simulation Services). Data was captured at a recording rate of $500 \mathrm{~ms}$. Carbon paper was placed either side of the sensor plate to remove anomalous readings due to inhomogeneous electrical contact with the PEFC plates. The sensor device was placed between the back of the cathode flow plate and the current collector, as shown in Figure 1(b).

\section{Results and Discussion}

\subsection{Effects of Self-Heating on Performance - Overall Cell Performance}

Figure 2(a) presents the polarisation plots for heated operation at 50,60 and $70{ }^{\circ} \mathrm{C}$ with hydrogen humidified at $30 \%$ and the case of no active-heating (self-heating) with varied hydrogen humidification due to a water bath temperature of $30^{\circ} \mathrm{C}$ but a varying cell temperature caused by self-heating. A relative humidity of $30 \%$ was chosen for the heated cases as they would exhibit similar conditions to the unheated case at higher current densities, where current density and temperature distributions are expected to be the most varied. All experiments were performed in counter-flow (configuration 1) and the air supply was not humidified.

For the actively heated systems, enhanced polarisation performance was observed with increasing cell temperature up to $60{ }^{\circ} \mathrm{C}$ at low-mid current densities $\left(<600 \mathrm{~mA} \mathrm{~cm}{ }^{-2}\right)$, corresponding to improved kinetics and sufficient membrane hydration.

Increasing to $70{ }^{\circ} \mathrm{C}$ resulted in degraded performance, suggesting membrane dehydration. A crude indicator of the heterogeneity of temperature (Figure 2(b)) and current density (Figure 2(c)) within the cell can be derived by subtracting the maximum and minimum localised values across the active area obtained by the mapping device. More detailed current and temperature maps will be described below. It can be seen that the $70{ }^{\circ} \mathrm{C}$ case exhibits significant performance heterogeneity, indicative of non-optimal performance, ultimately leading to a low limiting current density of $650 \mathrm{~mA} \mathrm{~cm}^{-2}$. The limiting current density is defined here as the final current density obtained through the polarisation analysis prior to a voltage drop to $0 \mathrm{~V}$. 


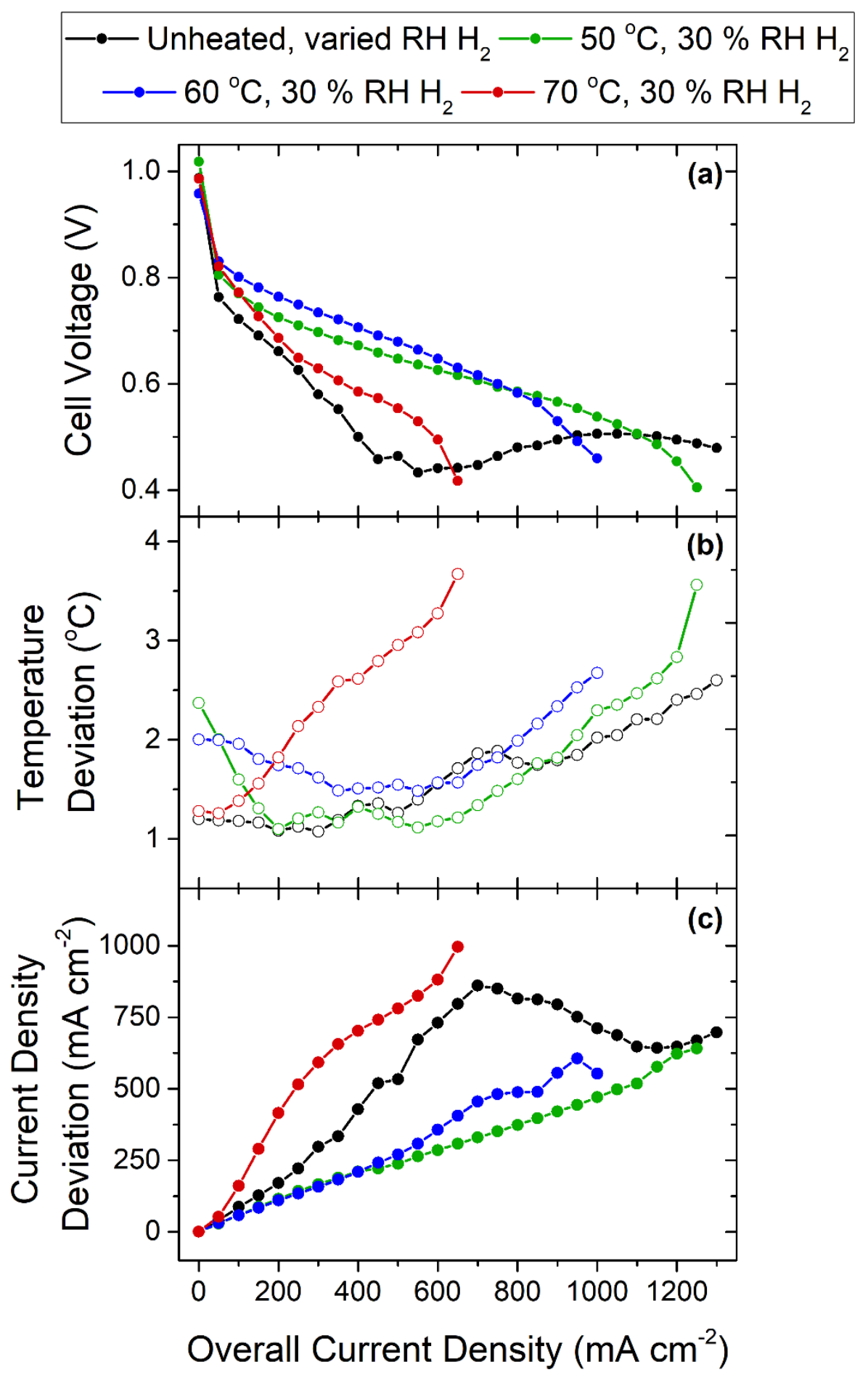

Figure 2 - (a) Polarisation performance, (b) temperature and (c) current density deviation across the active area during polarisation for self-heating operation with varied $\mathrm{RH} \mathrm{H}_{2}$ at a water bath temperature of $30^{\circ} \mathrm{C}$ and at 50,60 and $70{ }^{\circ} \mathrm{C}$ with $30 \% \mathrm{RH} \mathrm{H}_{2}$. 
The polarisation performance decline above $650 \mathrm{~mA} \mathrm{~cm}^{-2}$ for the $60{ }^{\circ} \mathrm{C}$ case is linked to its high operating temperature, resulting in membrane dehydration and increased current density and temperature heterogeneity across the cell's active area. The same phenomenon is observed for the $50^{\circ} \mathrm{C}$ case at $1100 \mathrm{~mA} \mathrm{~cm}^{-2}$, where the magnitude of heterogeneity is equal to the case of $60^{\circ} \mathrm{C}$ at $650 \mathrm{~mA} \mathrm{~cm}$.

The polarisation profile for the unheated case is an excellent example of how dynamically varying the temperature distorts the shape of the curve. The polarisation phenomenon exhibited is associated with the self-heating operation and subsequent changes in the relative humidity. At low current density, up to $\sim 600 \mathrm{~mA} \mathrm{~cm}{ }^{-2}$, poor performance is observed due to the low operating temperature $\left(<40{ }^{\circ} \mathrm{C}\right)$. Self-heating, as a consequence of operating at a higher current density, increases the cell temperature and improves performance, resulting in a 'voltage recovery' up to a point that is consistent with the $50^{\circ} \mathrm{C}$ case at $\sim 1100 \mathrm{~mA} \mathrm{~cm}^{-2}$. The lower operating temperature resulted in higher current density being reached $\left(\sim 65^{\circ} \mathrm{C}\right.$ at 1300 $\mathrm{mA} \mathrm{cm}^{-2}$ ), as the performance loss attributed to membrane dehydration was postponed. Operation above $1300 \mathrm{~mA} \mathrm{~cm}^{-2}$ was obtainable for the unheated case, but $1300 \mathrm{~mA} \mathrm{~cm}{ }^{-2}$ was selected as a suitable operating point for comparison with the heated cases in terms of current density and temperature heterogeneity.

It is important to note that in order to achieve this voltage recovery, it had been necessary to load the cell down to a voltage below the normal operational range (typ. $>0.5 \mathrm{~V}$ ); although, operation to these voltages are sometimes used as a means of self-heating in stacks as a cold-start strategy [16].

\subsection{Effect of Self-Heating on Performance - Local Current Density and Temperature Mapping}

More detail regarding the internal cell operation can be derived by considering the current and temperature distribution maps (Figure 3). Comparison is made in each case between the current distribution at an average current density of $100 \mathrm{~mA} \mathrm{~cm}^{-2}$ and that at the limiting current density (or $1300 \mathrm{~mA} \mathrm{~cm}^{-2}$ for the unheated case). Although typical PEFC operation would not extend to the limiting current density, it has been used in this analysis to accentuate the intrinsic relationship between temperature and current density by driving the cell to the extreme.

Considering first the profiles for the actively heated cells. At $100 \mathrm{~mA} \mathrm{~cm}{ }^{-2}$, the current is relatively evenly distributed, although there are already signs of reduced current in the cathode inlet / anode outlet zones for the $70^{\circ} \mathrm{C}$ case. 
For the limiting current density maps, increasing current density heterogeneity is observed with increasing temperature whilst the limiting current densities attained decreased from 1250 $\mathrm{mA} \mathrm{cm}$ at $50{ }^{\circ} \mathrm{C}$ to $650 \mathrm{~mA} \mathrm{~cm}{ }^{-2}$ at $70^{\circ} \mathrm{C}$. For the $50{ }^{\circ} \mathrm{C}$ case, the difference in local current density between the cathode inlet and outlet is $425 \mathrm{~mA} \mathrm{~cm}{ }^{-2}$, with the centre of the cell exhibiting the highest local current density $\left(1387 \mathrm{~mA} \mathrm{~cm}^{-2}\right)$ and temperature $\left(71.7^{\circ} \mathrm{C}\right)$.
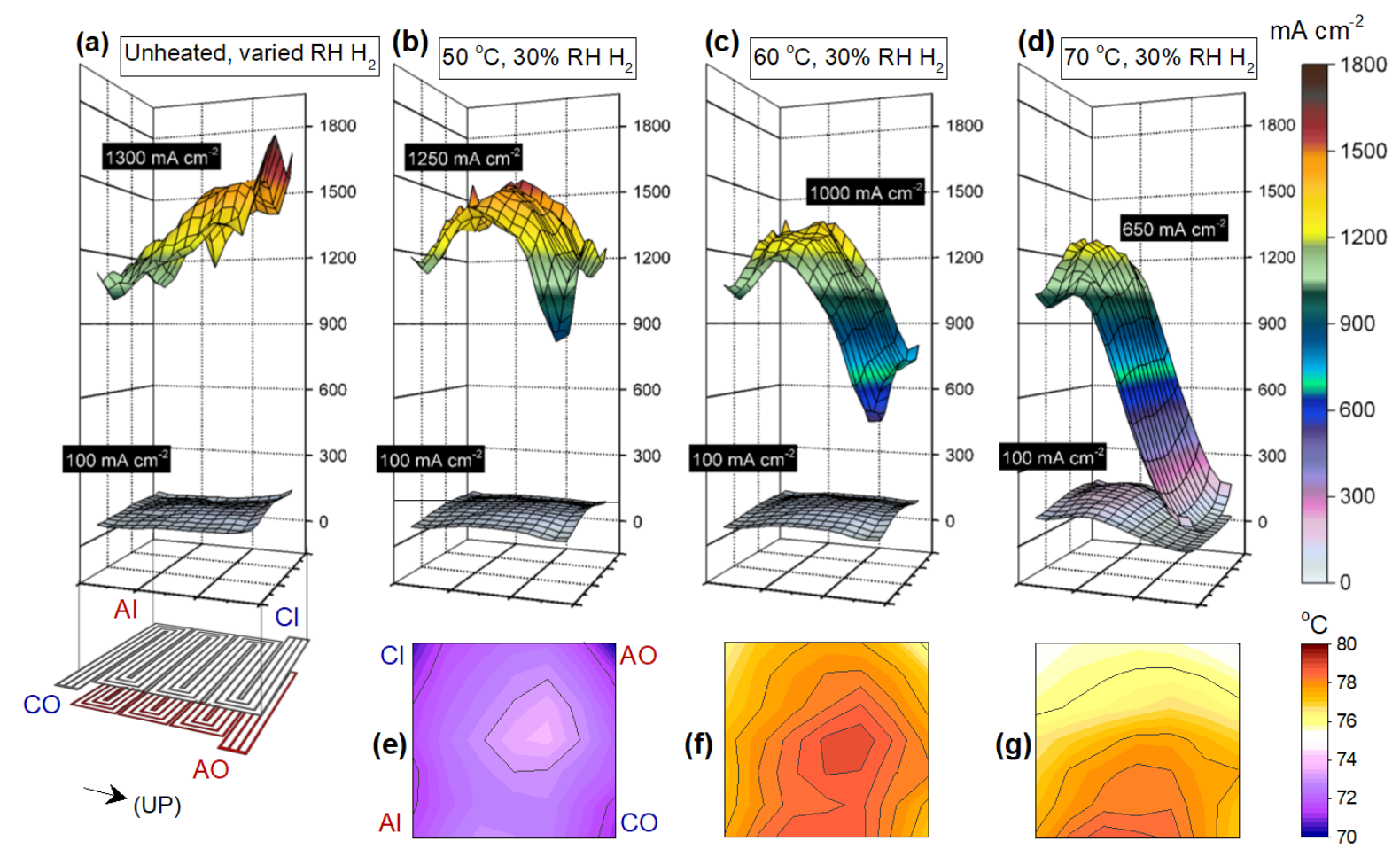

Figure 3 - (a-d) Current density maps at $100 \mathrm{~mA} \mathrm{~cm}^{-2}$ and the limiting current density for the heated cells and $1300 \mathrm{~mA} \mathrm{~cm}^{-2}$ for the unheated case; (e-g) thermal maps at the limiting current density across the active area during polarisation analysis for self-heating operation with (a) varied $\mathrm{RH} \mathrm{H}_{2}$ at a water bath temperature of $30^{\circ} \mathrm{C}$ and (b, e) operation at $50{ }^{\circ} \mathrm{C}$, (c, f) $60^{\circ} \mathrm{C}$ and (d, g) $70{ }^{\circ} \mathrm{C}$ with $30 \%$ $\mathrm{RH} \mathrm{H}$.

For increasing temperature, the difference in local current density between the cathode inlet / anode outlet and the cathode outlet / anode inlet zones widens, exhibiting a 'see-saw' effect. This is linked to both the increasingly high local temperatures at the cathode inlet region and the effects of no air humidification, which reduces local proton conductivity and results in membrane dehydration. The water produced by the electrochemical reaction at the cathode electrode is immediately vapourised and removed by the gas stream, instead of migrating to the membrane. This is most strikingly presented in the $70^{\circ} \mathrm{C}$ case, where the high temperature $\left(75^{\circ} \mathrm{C}\right)$ and lack of humidification at the cathode inlet has reduced the local current density $\left(130 \mathrm{~mA} \mathrm{~cm}^{-2}\right)$, which in turn has resulted in a lower local temperature due to the reduced local 
heat generation compared to the outlet. Similar results were obtained by Peng et al. for the middle cell of a $250 \mathrm{~cm}^{2}, 3 \mathrm{~kW}$ stack heated to $70{ }^{\circ} \mathrm{C}$ [54], with emphasised membrane dehydration in the inlet region when both reactants and coolant fluid entered in the same through-plane location. The co-flow arrangement observed a region of high temperature (inlet gas heated to $70^{\circ} \mathrm{C}$ ) and low humidity at the inlet, resulting in a low local water content and proton conductivity. Dry regions in the membrane lead to uneven current density which lowered the local performance. The thermal map for the $70{ }^{\circ} \mathrm{C}$ case at the limiting current density in Figure 3(g) mirrors the current density distribution in Figure 3(d) (local heat generation variation), with the coolest location near the cathode inlet and the hottest near the anode inlet.

Conversely, the humidification of the hydrogen gas line and possible liquid water pooling near the cathode outlet (which maintains local hydration [45]) has resulted in a high local performance at the limiting current density. Numerous neutron imaging studies have observed the highest liquid water presence in the final serpentine bend in the cathode flow channels and near the outlet regions when air is flowing with gravity [55-57]. If the cell is heated and the reactants humidified, overall water mass decreases with current density as rising local temperatures from self-heating vapourise liquid water predominantly in the channels [58-60]. For heated operation with only the hydrogen feed humidified, the input of water humidifies the anode channel and offsets the membrane dehydration by the dry air stream [61]. In the case of PEFCs operated unheated and without external humidification, water produced by the electrochemical reaction at low current densities and low temperatures remains in liquid form and migrates to the serpentine channel where it accumulates [62]. With increasing current density and rising cell temperatures from self-heating, liquid water presence declines prior to membrane dehydration $[29,63]$.

For the unheated case, although its heterogeneity in current density at $1300 \mathrm{~mA} \mathrm{~cm} \mathrm{~cm}^{-2}$ was similar to the $50{ }^{\circ} \mathrm{C}$ case at $1250 \mathrm{~mA} \mathrm{~cm}^{-2}$, its current density map (Figure 3(a)) exhibited the highest local current densities in the cathode inlet / anode outlet zones. Local temperatures at the cathode inlet were almost $10^{\circ} \mathrm{C}$ colder for the unheated operation compared to the $50{ }^{\circ} \mathrm{C}$ case, resulting in a better local membrane humidity. Local current densities decreased towards the bottom of the cell, in the region of the cathode outlet / anode inlet. This effect of a lower cell temperature $\left(\sim 60^{\circ} \mathrm{C}\right)$ and high hydrogen inlet humidification can induce local liquid water pooling, that has been frequently observed in neutron imaging studies [29, 62, 63]. The greater density of liquid water accumulation may obstruct the reactant supply to the electrodes, thus reducing its local current density. 


\subsection{Gas Flow Orientation in Self-Heated Mode - Overall Cell Performance}

The overall polarisation performance for each flow orientation is displayed in Figure 4. Flow configuration 1 and 4 are in a counter-flow orientation and 2 and 3 are cross-flow, as labelled in Figure 1. At low current densities $\left(<200 \mathrm{~mA} \mathrm{~cm}{ }^{-2}\right)$, where performance is dominated by reaction kinetics, the counter-flow orientations exhibited poorer performance than the crossflow cases. In the mid-current density region (200-800 $\left.\mathrm{mA} \mathrm{cm}^{-2}\right)$, a decrease in voltage with a similar gradient fall for all flow configurations is observed, followed by the voltage recovery phenomenon.

Cell performance improves with current density above $600 \mathrm{~mA} \mathrm{~cm}^{-2}$ for all flow orientations. This critical interchange is attributed to the self-heating phenomenon, as the higher current density operation has raised the cell temperature, thus improving reaction kinetics, electrolyte conductivity and water transport. Between $600-1000 \mathrm{~mA} \mathrm{~cm}^{-2}$, all flow configurations display almost identical voltage recoveries irrespective of reactant flow direction, suggesting that the effects of self-heating has subdued the dominating mass transport mechanisms which draw attention to the effects of flow orientation.

Above $1000 \mathrm{~mA} \mathrm{~cm}{ }^{-2}$, the disparity in performance reappears, with a faster performance deterioration with the cross-flow orientations (2 and 3 ).

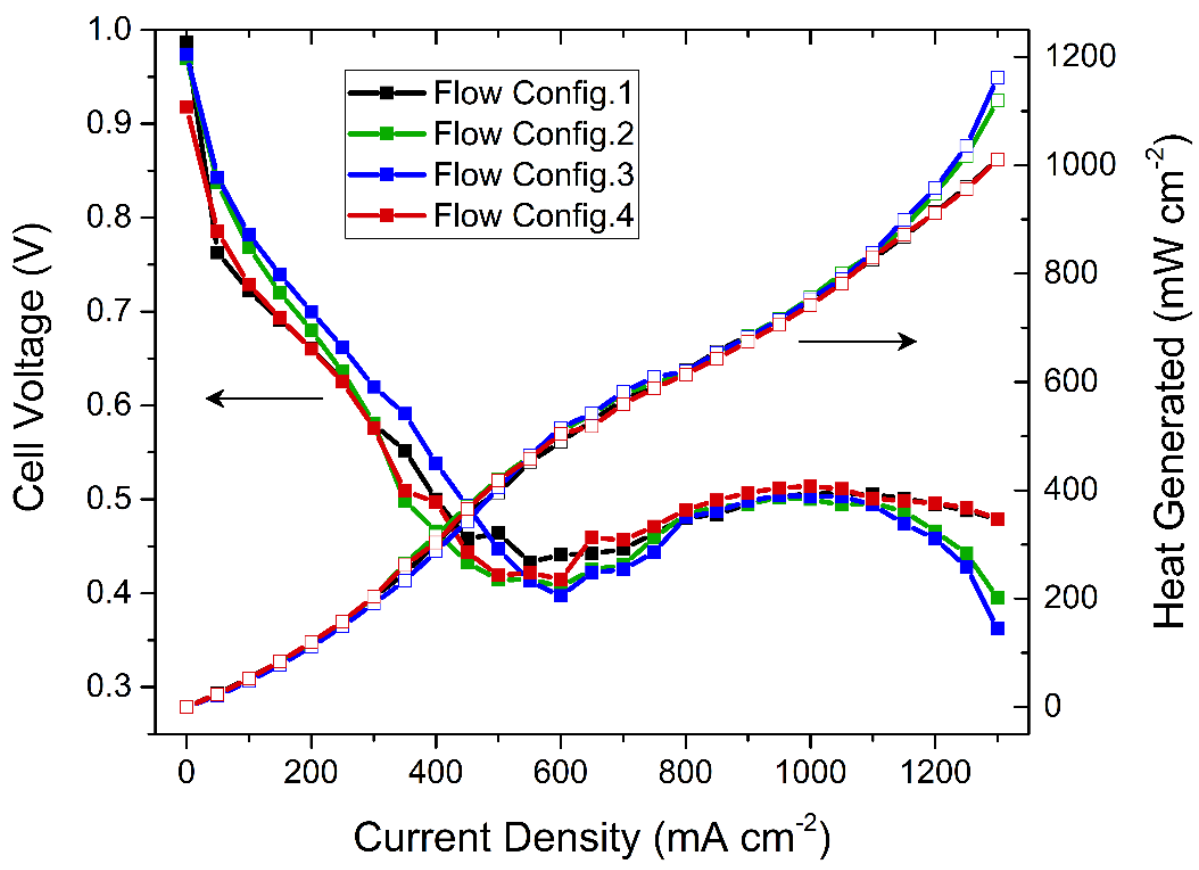

Figure 4 - Polarisation performance and heat generation rate of the different flow configurations. 


\subsection{Gas Flow Orientation in Self-Heated Mode - Local Current Density and Temperature Mapping}

The current density and temperature maps at 100,700 and $1300 \mathrm{~mA} \mathrm{~cm}{ }^{-2}$ are presented for each flow configuration in Figures 5-8(a-c). Figure 5-8(e, f) present the local current density and temperature profiles for five prominent locations in each flow configuration; cathode inlet, first cathode bend / anode inlet / anode outlet, centre, final cathode bend / anode inlet / outlet and the cathode outlet. Figure 9 shows the current density and temperature deviation across the active area for the complete polarisation curve as a quantification of the extent of spatial performance heterogeneity

The current density and temperature profiles at $100 \mathrm{~mA} \mathrm{~cm}^{-2}$ are both comparatively uniform for each of the different flow configurations $\left(<85 \mathrm{~mA} \mathrm{~cm}{ }^{-2}\right.$ and $<1.18{ }^{\circ} \mathrm{C}$ disparity). Slight gradients lowering from the cathode inlet towards the cathode outlet were captured, irrespective of flow orientation or hydrogen flow direction, indicating that even at $100 \mathrm{~mA} \mathrm{~cm}$ ${ }^{2}$, reactant and water distributions impact the spatial performance, despite operating with sufficient air flow [64].

Operation from $700 \mathrm{~mA} \mathrm{~cm}{ }^{-2}$ marks the approximate onset of the voltage recovery, with the current density deviations (Figure 9) reaching a maximum and representing the zone of maximum temperature and current heterogeneity. This suggests that a greater thermal disparity across the MEA promotes a more heterogeneous current density distribution, or vice versa. For all orientations, the highest local current density is detected in the straight channel containing the cathode inlet, with a larger skew when both reactant inlets are placed in the same lateral plane, as with the cross-flow orientations (2 and 3 ). This is due to a higher reactant concentration in this region $[5,49]$, which enhances kinetics and increases the local current density [65]. A higher heat generation rate ensues, raising the local temperature, further improving the reaction kinetics and so on. The performance gradually diminishes along the flow path towards the cathode outlet, with a larger affected area encompassing the final serpentine bends where water is expected to accumulate more readily, as has been identified by modelling [53] and neutron imaging studies [29, 62, 63]. If the anode inlet is placed on the same lateral plane as the cathode outlet, as with the counter-flow configurations in 1 and 4 , this negative skew towards the cathode outlet is slightly improved, resulting in a more uniform temperature and current density distribution. Studies have attributed this to counter-flow orientations promoting a more uniform water distribution, alleviating localised pockets of dehydration and flooding [66]. 
Configuration 3 exhibits the largest temperature variance of $2.65^{\circ} \mathrm{C}$ at $700 \mathrm{~mA} \mathrm{~cm}$, with the hottest region in the top half of the MEA where the inlets are located. Its current density map at $700 \mathrm{~mA} \mathrm{~cm}^{-2}$ in Figure $7(\mathrm{a}, \mathrm{b})$ corresponds to its thermal distribution in Figure 7 (c), with an overall deviation of $1080 \mathrm{~mA} \mathrm{~cm}^{-2}$. The deviation is further exacerbated by the cooling effects of the expected pooled water in the bottom half of the flow-field by the downward reactant flow. It should be noted that the recorded temperature distributions are a proxy for the temperature at the MEA/electrodes, as they are measured behind the flow plate [67, 68]; however, they are useful in observing the spatial variations but not the absolute values. The effect of temperature distributions on local degradation have not been thoroughly investigated in the literature; however, a small number of modelling studies have alluded to high thermal stresses on the MEA at high current densities [69-71].

The current density and thermal maps of the counter-flow orientations ( 1 and 4 ) at $700 \mathrm{~mA}$ $\mathrm{cm}^{-2}$ also exhibit relatively high heterogeneity. Although, at this junction in the polarisation curve, the counter-flow orientations present a more uniform current density and temperature distribution compared to the cross-flow orientations. Studies have attributed this to the improved water distribution with counter-flow orientation [41-44].

At $1300 \mathrm{~mA} \mathrm{~cm}$, a more uniform current density distribution is observed for all flow configurations compared to $700 \mathrm{~mA} \mathrm{~cm}$. This is attributed to the self-heating phenomenon, where the raised cell temperature may have homogenised the water distribution, which in turn has homogenised the current density and heat generation. However, thermal distributions remain high for all flow orientations with the colder regions near the unheated gas inlets and the hottest at the centre of the cell where heat is not so easily dissipated by conduction. 
(a)
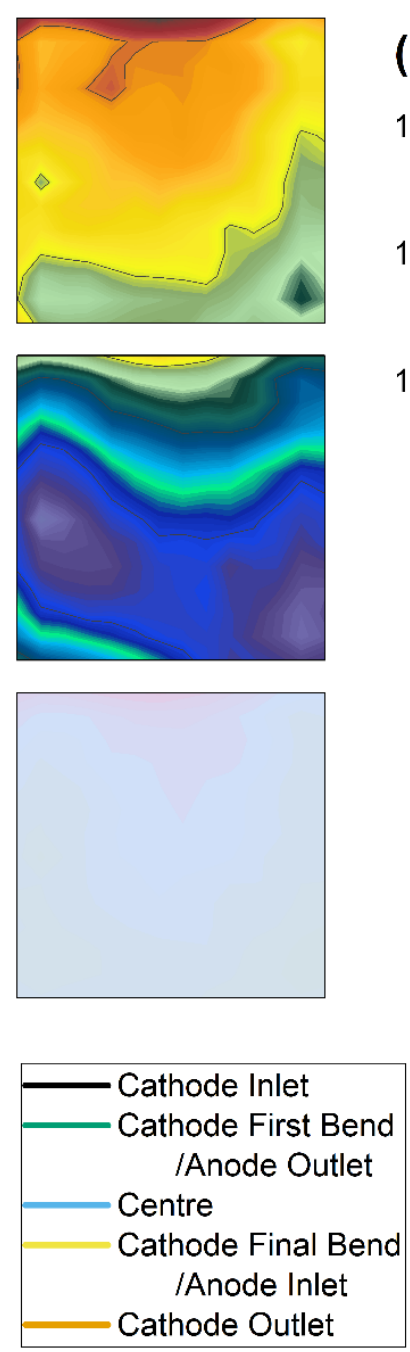

(e)

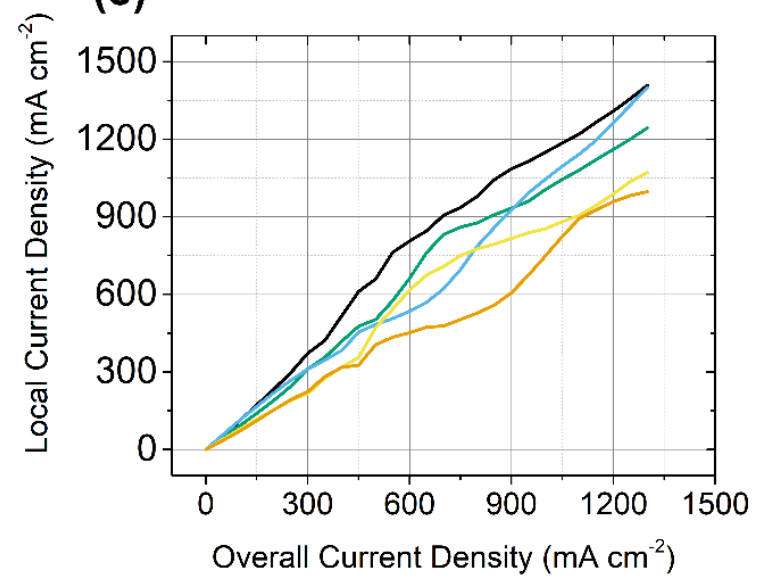

CO (c) Temperature $\left({ }^{\circ} \mathrm{C}\right)$
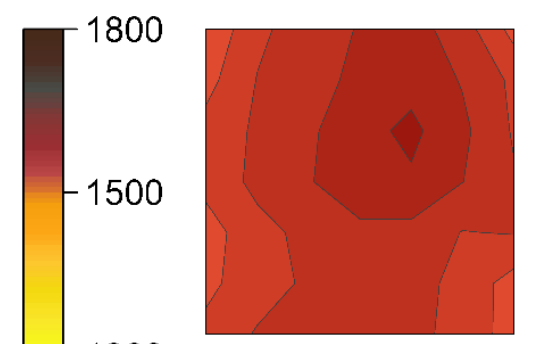

64

59

54

49

44

39

34

$-300$
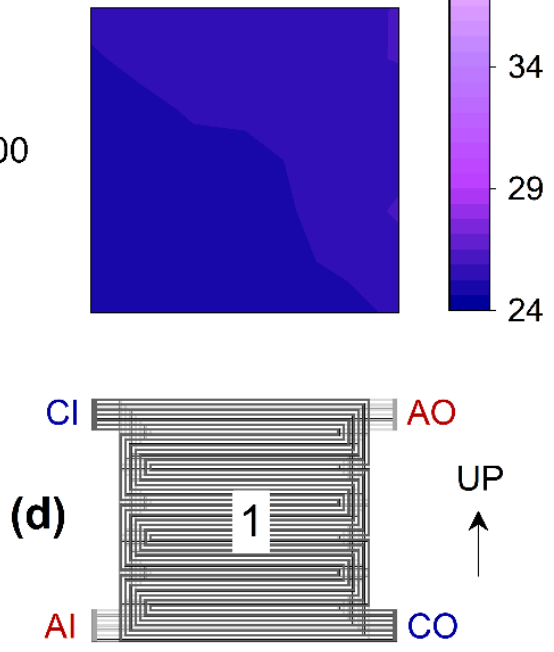

(f)

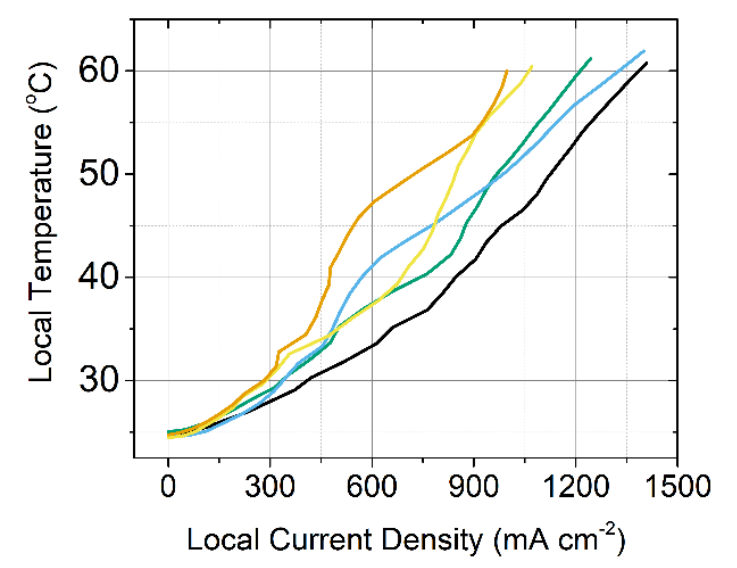

Figure 5 - Current density (a, b) and thermal maps (c) at 100, 700 and $1300 \mathrm{~mA} \mathrm{~cm}^{-2}$ for flow configuration 1 (d). Local current densities (e) and temperature profiles (f) during polarisation. 
(a)
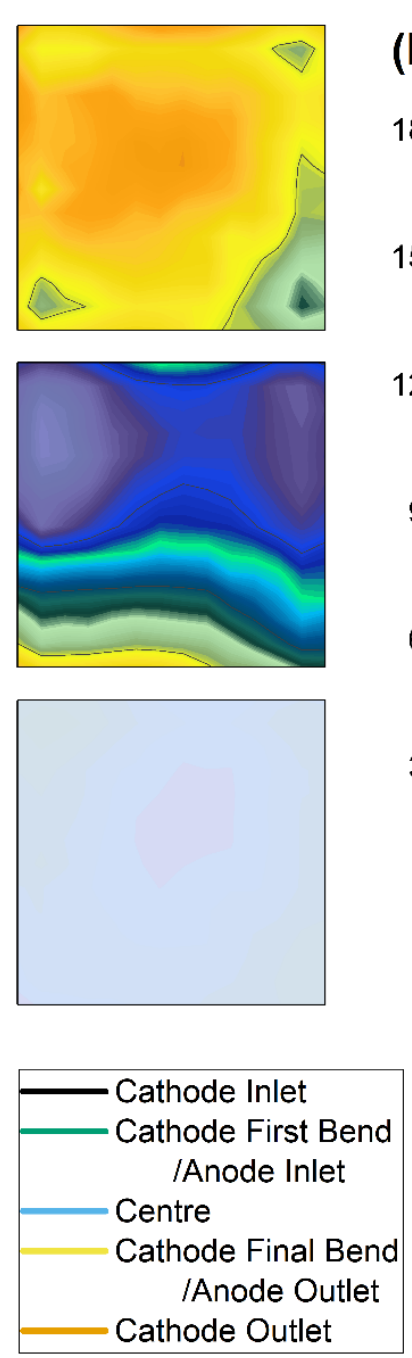

(e)

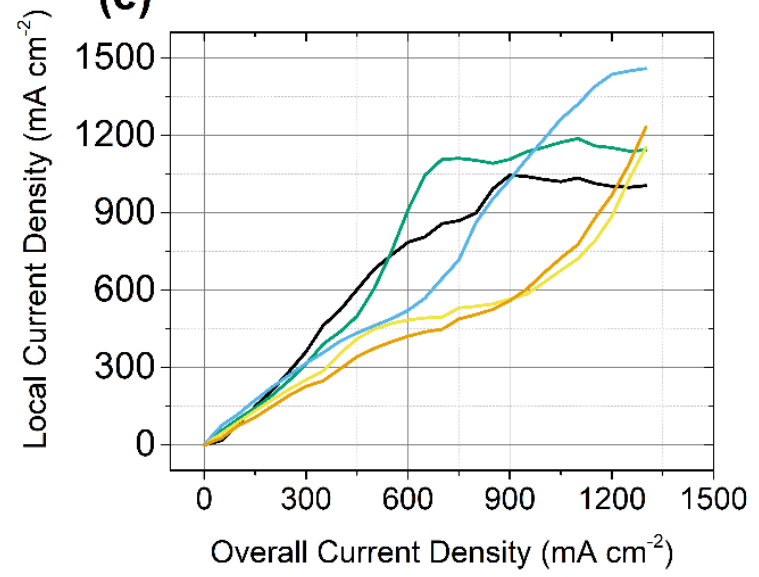

(c) Temperature $\left({ }^{\circ} \mathrm{C}\right)$
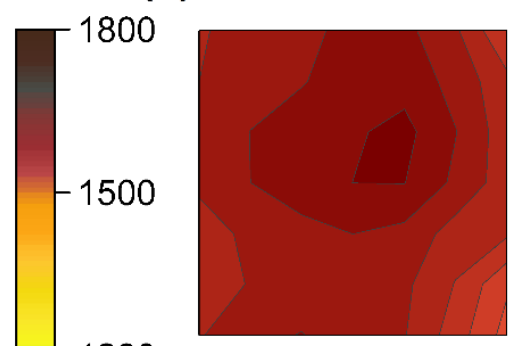

? 64

59

54

49

44

39

34

$-300$

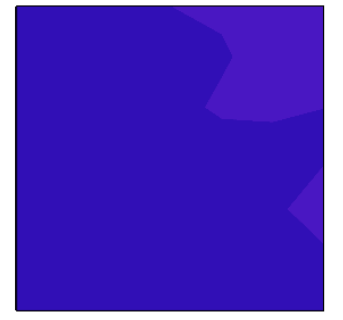

29

$\perp_{0}$

24

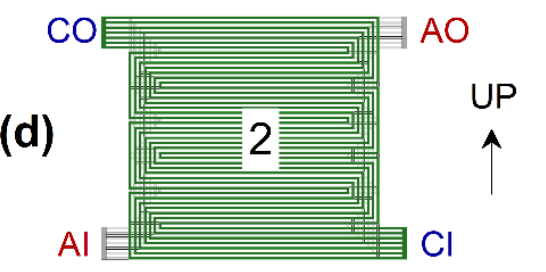

Figure 6 - Current density (a, b) and thermal maps (c) at 100, 700 and $1300 \mathrm{~mA} \mathrm{~cm}{ }^{-2}$ for flow configuration 2 (d). Local current densities (e) and temperature profiles (f) during polarisation. 
(a)
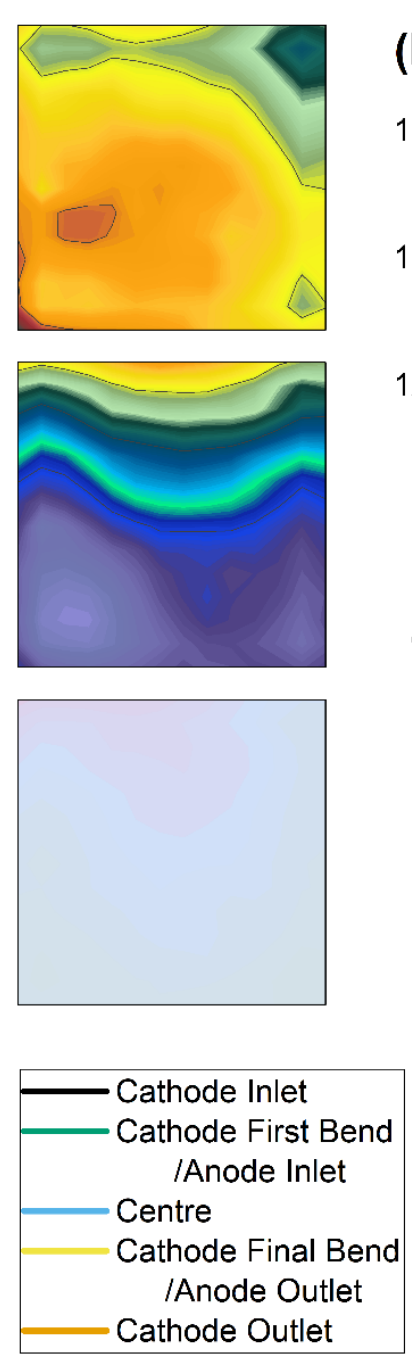

(e)

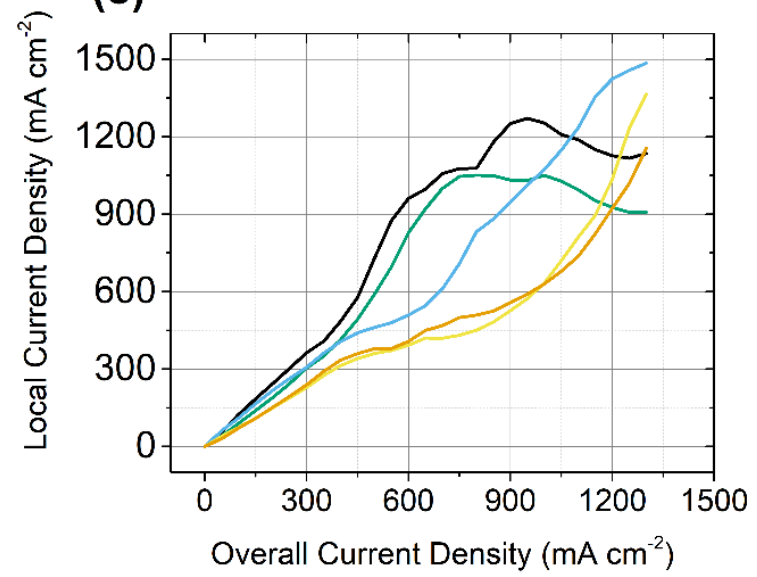

$\mathrm{CO}$ (c) Temperature $\left({ }^{\circ} \mathrm{C}\right)$

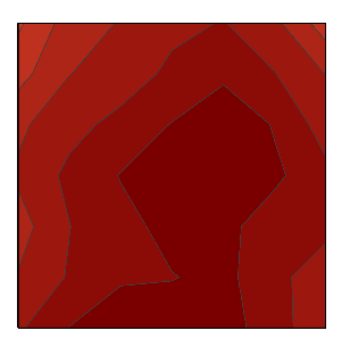

64

59

54

49

44

39

34

$-300$
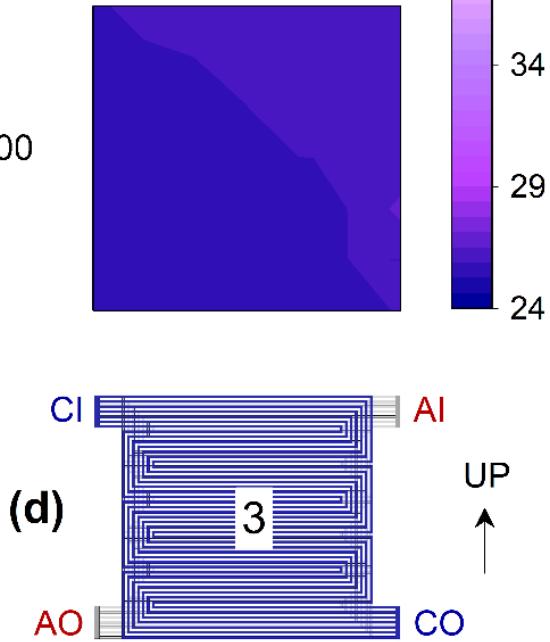

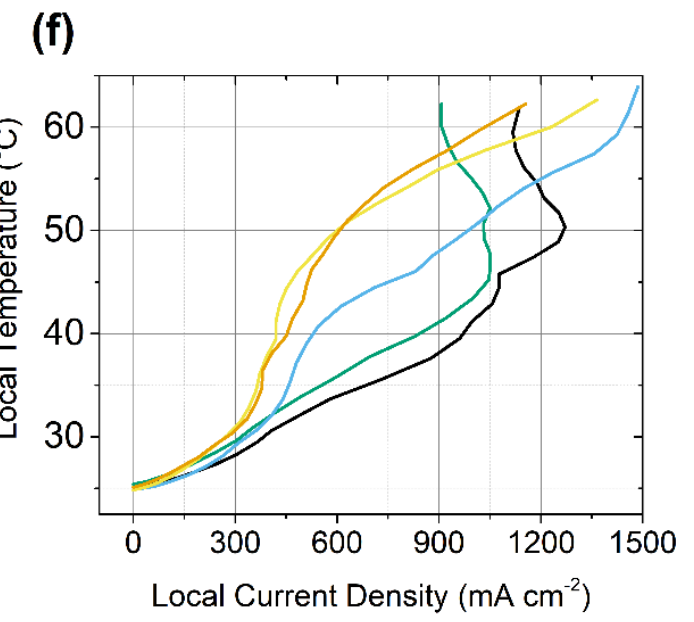

Figure 7 - Current density (a, b) and thermal maps (c) at 100, 700 and $1300 \mathrm{~mA} \mathrm{~cm}-2$ for flow configuration 3 (d). Local current densities (e) and temperature profiles (f) during polarisation. 
(a)
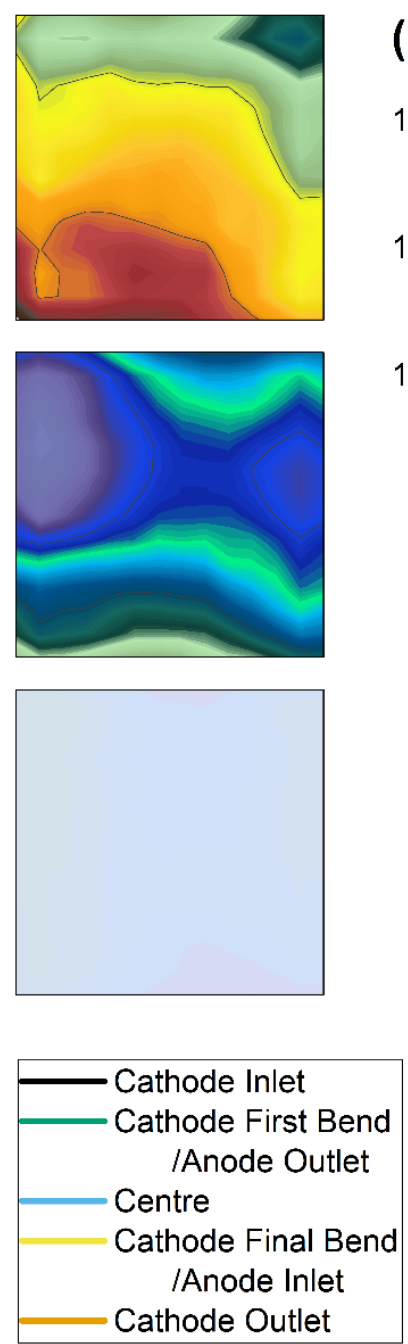

(e)

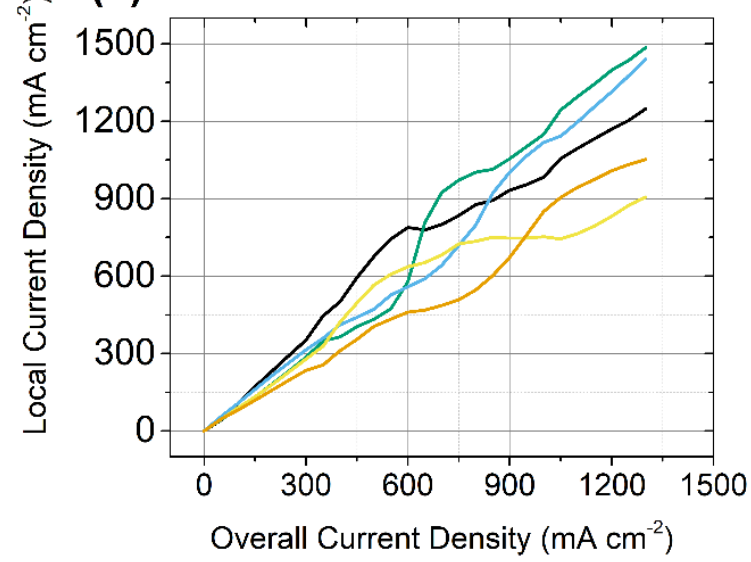

$\mathrm{Cl}$ (c) Temperature $\left({ }^{\circ} \mathrm{C}\right)$

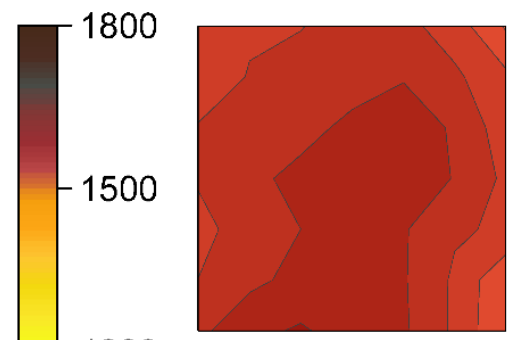

59

54

49

44

39

34

$-300$

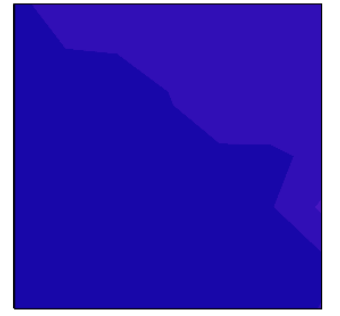

29

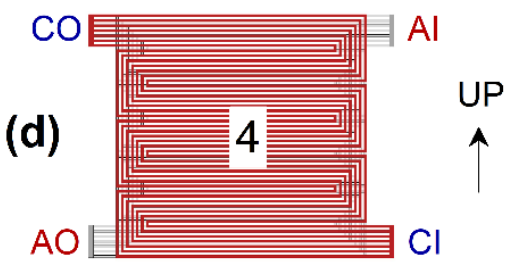

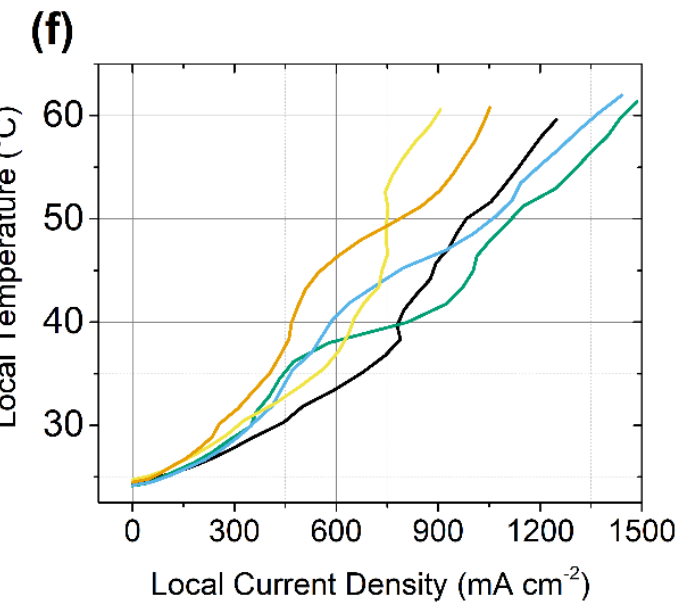

Figure 8 - Current density (a, b) and thermal maps (c) at 100, 700 and $1300 \mathrm{~mA} \mathrm{~cm}^{-2}$ for flow configuration 4 (d). Local current densities (e) and temperature profiles (f) during polarisation. 
For counter-flow orientations ( 1 and 4 ), higher local current densities are still detected near the cathode inlet / anode outlet zone and conversely low current densities near the cathode outlet / anode inlet, with a more homogeneous current density distribution with the descending flow of air with gravity (configuration 1). This corroborates with the segmented cell study by Weng et al., who observed a more uniform current density distribution when operating in counter-flow with air flowing with gravity [43]. Consistent with the thermal maps, configuration 1 observes a more homogeneous thermal distribution, as the descending air flow has the capacity to distribute heat and water more effectively than the hydrogen flow [72].

Cross-flow orientations (2 and 3) at $1300 \mathrm{~mA} \mathrm{~cm}^{-2}$ achieve high temperature heterogeneities across the active area $\left(3.56{ }^{\circ} \mathrm{C}\right.$ and $3.33^{\circ} \mathrm{C}$, respectively), but not the highest spatial current density disparity (476 mA cm${ }^{-2}$ and $803.56 \mathrm{~mA} \mathrm{~cm}^{-2}$, respectively). This suggests that factors such as reactant concentration and water distribution also contribute to the performance variation [73]. Between the two cross-flow orientations, the upward flow of reactants (configuration 2) is expected to preserve more water within the cell to offset the effects of dehydration [46], which has resulted in a more uniform current density distribution.

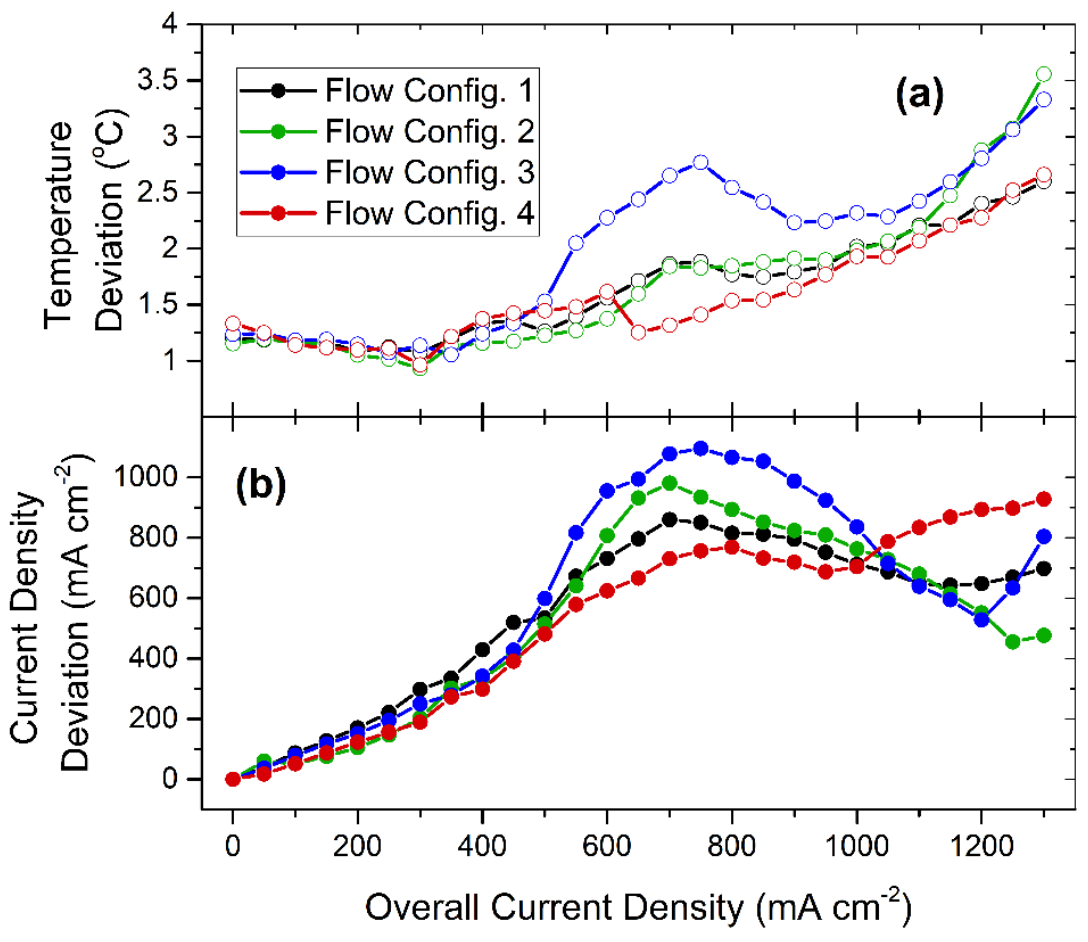

Figure 9 - (a) Temperature and (b) current density deviation across the active area during polarisation analysis for each flow configuration. 
The thermal maps in Figures 5-8(c) for all flow configurations display a growing heat spot with increasing current density. At low-mid current densities, the location of the maximum temperature follows the region of higher current density, which at $700 \mathrm{~mA} \mathrm{~cm}{ }^{-2}$ occurs close to the cathode inlet, irrespective of the anode inlet placement. However, if the anode and cathode inlets are placed on the same lateral place (cross-flow 2 and 3), the thermal distribution is more heavily skewed. Hakenjos et al. observed high local temperatures in regions of high current density when no liquid water was present in the cell and low local current densities where condensed water collected as gas transport in the porous media was restricted [8]. For all flow configurations, their thermal maps at $1300 \mathrm{~mA} \mathrm{~cm}{ }^{-2}$ observed local peak temperatures at the centre of the cell, veering towards the anode outlet. Although these weren't the locations of the highest local current density, the heat removal rate is greater around the edges of the active area than the centre.

\section{Conclusion}

This work highlights the importance of considering the natural self-heating effect on the polarisation curve, in addition to conventional isothermal (controlled) temperature fuel cell operation. This is particularly important for systems without active heating / cooling and for those that rely on self-heating for cold-start operation. By comparing self-heated cells with actively heated systems and using localised current and temperature mapping, it is found that the complex interplay between current, water and temperature can lead to a highly heterogeneous spatial distribution of performance. At low-mid current densities in unheated cells, insufficient heat is produced to achieve good performance and their current density profile becomes exceedingly heterogeneous. The effect of cell flooding and subsequent evaporation with increasing current density leads to a cell 'reactivation' (voltage recovery) event associated with the self-heating operation.

The effects of flow orientation for a 'self-heating' cell were investigated for counter and crossflow orientations. Depending on the operating regime and flow-field design, different orientations can be advantageous. Between the flow orientations, little difference was observed in their overall cell performance. However, when observing their spatial heterogeneities in current density and temperature across the active area, a counter-flow orientation with air flowing with gravity presented the best homogeneity. Its current and temperature maps show a combined lower deviation than the other flow configurations, which can slow degradation rates attributed to MEA stress during the PEFC lifetime. As an example, thermal distributions affect the water-vapour distribution by condensation and local membrane 
dehydration, increasing the likelihood of localised degradation and pin-hole formation [74]. The effect of 'self-heating' has shown to present adequate performance at high current densities after the voltage recovery stage, without requiring active heating. However, excessive temperatures that may lead to local membrane dehydration become an issue with increasing current density and active cooling techniques would need to be applied.

\section{Acknowledgements}

The authors would like to acknowledge funding from the EPSRC (EP/L015277/1, EP/P009050/1, EP/M014371/1, EP/M009394/1, EP/M023508/1, EP/L015749/1, EP/N022971/1) for supporting fuel cell research in the Electrochemical Innovation Lab (EIL) and to the Digital Engineering and Test Centre (APC Spoke) Virtually Connected Hybrid Vehicle (VCHV) project for supporting Lara Rasha.

\section{References}

1. Shao, H., et al., In-situ measurement of temperature and humidity distribution in gas channels for commercial-size proton exchange membrane fuel cells. Journal of Power Sources, 2019. 412: p. 717724.

2. Burheim, O.S. and B.G. Pollet, Thermal gradients and thermal conductivity in PEM fuel cells, compared to Li-Ion batteries and super capacitors. ECS Transactions, 2018. 86(13): p. 97-109.

3. Kim, H.-S. and K. Min, An experimental investigation of temperature distribution and flooding phenomena of cathode flow fields in a proton exchange membrane (PEM) fuel cell. Journal of Mechanical Science and Technology, 2014. 28(9): p. 3837-3843.

4. Jung, C.-Y., et al., Investigations of the temperature distribution in proton exchange membrane fuel cells. Applied Energy, 2012. 93: p. 733-741.

5. Yu, Y., et al., Current mapping of a proton exchange membrane fuel cell with a segmented current collector during the gas starvation and shutdown processes. International Journal of Hydrogen Energy, 2012. 37(20): p. 15288-15300.

6. Rodatz, P., et al., Operational aspects of a large PEFC stack under practical conditions. Journal of Power Sources, 2004. 128(2): p. 208-217.

7. Abdullah, A.M., et al., Temperature gradients measurements within a segmented H2/air PEM fuel cell. Journal of Power Sources, 2007. 172(1): p. 209-214.

8. Hakenjos, A., et al., A PEM fuel cell for combined measurement of current and temperature distribution, and flow field flooding. Journal of Power Sources, 2004. 131(1): p. 213-216.

9. Chen, F.C., et al., Analysis of optimal heat transfer in a PEM fuel cell cooling plate. Fuel Cells, 2003. 3(4): p. 181-188.

10. Asghari, S., H. Akhgar, and B.F. Imani, Design of thermal management subsystem for a $5 \mathrm{~kW}$ polymer electrolyte membrane fuel cell system. Journal of Power Sources, 2011. 196(6): p. 3141-3148.

11. Wu, J., et al., An air-cooled proton exchange membrane fuel cell with combined oxidant and coolant flow. Journal of Power Sources, 2009. 188(1): p. 199-204. 
12. Faghri, A. and Z. Guo, Challenges and opportunities of thermal management issues related to fuel cell technology and modeling. International Journal of Heat and Mass Transfer, 2005. 48(19): p. 3891-3920.

13. Bargal, M.H.S., et al., Liquid cooling techniques in proton exchange membrane fuel cell stacks: A detailed survey. Alexandria Engineering Journal, 2020. 59(2): p. 635-655.

14. Zhang, G. and S.G. Kandlikar, A critical review of cooling techniques in proton exchange membrane fuel cell stacks. International Journal of Hydrogen Energy, 2012. 37(3): p. 2412-2429.

15. Zhang, J., et al., High temperature PEM fuel cells. Journal of Power Sources, 2006. 160(2): p. 872-891.

16. Jiang, F. and C.-Y. Wang, Potentiostatic start-up of PEMFCs from subzero temperatures. Journal of The Electrochemical Society, 2008. 155(7): p. B743.

17. Shao, Y., et al., Proton exchange membrane fuel cell from low temperature to high temperature: Material challenges. Journal of Power Sources, 2007. 167(2): p. 235-242.

18. Lochner, T., et al., Temperature effects in polymer electrolyte membrane fuel cells. ChemElectroChem, 2020. 7(17): p. 3545-3568.

19. Noorkami, M., et al., Effect of temperature uncertainty on polymer electrolyte fuel cell performance. International Journal of Hydrogen Energy, 2014. 39(3): p. 1439-1448.

20. Meyer, Q., et al., Combined current and temperature mapping in an air-cooled, open-cathode polymer electrolyte fuel cell under steady-state and dynamic conditions. Journal of Power Sources, 2015. 297: p. 315-322.

21. Xing, L., et al., A segmented fuel cell unit with functionally graded distributions of platinum loading and operating temperature. Chemical Engineering Journal, 2021. 406: p. 126889.

22. Takanohashi, K., et al., Simultaneous visualization of oxygen partial pressure, current density, and water droplets in serpentine fuel cell during power generation for understanding reaction distributions. Journal of Power Sources, 2017. 343: p. 135-141.

23. Lochner, T., et al., Local degradation effects in automotive size membrane electrode assemblies under realistic operating conditions. Applied Energy, 2020. 260: p. 114291.

24. Dai, W., et al., A review on water balance in the membrane electrode assembly of proton exchange membrane fuel cells. International Journal of Hydrogen Energy, 2009. 34(23): p. 9461-9478.

25. Li, X. and I. Sabir, Review of bipolar plates in PEM fuel cells: Flow-field designs. International Journal of Hydrogen Energy, 2005. 30(4): p. 359-371.

26. Sauermoser, M., et al., Flow field patterns for proton exchange membrane fuel cells. Frontiers in Energy Research, 2020.8(13).

27. Liu, H., et al., Experimental study and comparison of various designs of gas flow fields to PEM fuel cells and cell stack performance. Frontiers in Energy Research, 2014. 2(2).

28. Aiyejina, A. and M.K.S. Sastry, PEMFC flow channel geometry optimization: A review. Journal of Fuel Cell Science and Technology, 2011. 9(1).

29. Wu, Y., et al., Effect of serpentine flow-field design on the water management of polymer electrolyte fuel cells: An in-operando neutron radiography study. Journal of Power Sources, 2018. 399: p. 254-263.

30. Kandlikar, S.G., et al., Measurement of flow maldistribution in parallel channels and its application to ex-situ and in-situ experiments in PEMFC water management studies. International Journal of Heat and Mass Transfer, 2009. 52(7): p. 1741-1752.

31. Liu, X., et al., Water flooding and pressure drop characteristics in flow channels of proton exchange membrane fuel cells. Electrochimica Acta, 2007. 52(11): p. 3607-3614.

32. Liu, Z., et al., Behavior of PEMFC in starvation. Journal of Power Sources, 2006. 157(1): p. 166-176.

33. Whiteley, M., et al., A novel polymer electrolyte fuel cell flow-field: The through-plane array. Journal of Power Sources, 2019. 442: p. 227218.

34. Sajid Hossain, M. and B. Shabani, Metal foams application to enhance cooling of open cathode polymer electrolyte membrane fuel cells. Journal of Power Sources, 2015. 295: p. 275-291. 
35. Koresawa, R. and Y. Utaka, Water control by employing microgrooves inside gas channel for performance improvement in polymer electrolyte fuel cells. International Journal of Hydrogen Energy, 2015. 40(25): p. 8172-8181.

36. Bao, C., M. Ouyang, and B. Yi, Modeling and control of air stream and hydrogen flow with recirculation in a PEM fuel cell system-I. Control-oriented modeling. International Journal of Hydrogen Energy, 2006. 31(13): p. 1879-1896.

37. Hwang, J.J., et al., Effect of flow orientation on thermal-electrochemical transports in a PEM fuel cell. Journal of Power Sources, 2006. 157(1): p. 85-97.

38. Kimball, E., et al., Drops, slugs, and flooding in polymer electrolyte membrane fuel cells. AIChE Journal, 2008. 54(5): p. 1313-1332.

39. Yi, Y., et al., Gravity effect on the performance of PEM fuel cell stack with different gas manifold positions. International Journal of Energy Research, 2012. 36(7): p. 845-855.

40. Chen, S. and Y. Wu, Gravity effect on water discharged in PEM fuel cell cathode. International Journal of Hydrogen Energy, 2010. 35(7): p. 2888-2893.

41. Yang, W., D. Cha, and Y. Kim, Effects of flow direction on dynamic response and stability of nonhumidification PEM fuel cell. Energy, 2019. 185: p. 386-395.

42. Lin, C., et al., Optimization of configurations and cathode operating parameters on liquid-cooled proton exchange membrane fuel cell stacks by orthogonal method. Applied Energy, 2019. 253: p. 113496.

43. Weng, F.-B., et al., The effect of low humidity on the uniformity and stability of segmented PEM fuel cells. Journal of Power Sources, 2008. 181(2): p. 251-258.

44. Alaefour, I., et al., Measurement of current distribution in a proton exchange membrane fuel cell with various flow arrangements - A parametric study. Applied Energy, 2012. 93: p. 80-89.

45. Kim, T., et al., Experimental approaches for distribution and behavior of water in PEMFC under flow direction and differential pressure using neutron imaging technique. Nuclear Instruments and Methods in Physics Research Section A: Accelerators, Spectrometers, Detectors and Associated Equipment, 2009. 600(1): p. 325-327.

46. Morin, A., et al., Influence of PEMFC gas flow configuration on performance and water distribution studied by SANS: Evidence of the effect of gravity. International Journal of Hydrogen Energy, 2011. 36(4): p. 3096-3109.

47. Pérez, L.C., et al., Segmented polymer electrolyte membrane fuel cells-A review. Renewable and Sustainable Energy Reviews, 2011. 15(1): p. 169-185.

48. Kalyvas, C., et al., Spatially resolved diagnostic methods for polymer electrolyte fuel cells: a review. Wiley Interdisciplinary Reviews: Energy and Environment, 2014. 3(3): p. 254-275.

49. Belhadj, M., et al., Current density distributions in polymer electrolyte fuel cells: $A$ tool for characterisation of gas distribution in the cell and its state of health. Chemical Engineering Science, 2018. 185: p. 18-25.

50. Geske, M., et al., Current density distribution mapping in PEMfuel cells as an instrument for operational measurements. Energies, 2010. 3(4): p. 770.

51. Rajalakshmi, N., M. Raja, and K.S. Dhathathreyan, Evaluation of current distribution in a proton exchange membrane fuel cell by segmented cell approach. Journal of Power Sources, 2002. 112(1): p. 331-336.

52. Natarajan, D. and T. Van Nguyen, Current distribution in PEM fuel cells. Part 1: Oxygen and fuel flow rate effects. AIChE Journal, 2005. 51(9): p. 2587-2598.

53. Hwnag, J.J., et al., Experimental and numerical studies of local current mapping on a PEM fuel cell. International Journal of Hydrogen Energy, 2008. 33(20): p. 5718-5727.

54. Peng, L., et al., Investigation of the non-uniform distribution of current density in commercial-size proton exchange membrane fuel cells. Journal of Power Sources, 2020. 453: p. 227836. 
55. Zhang, J., et al., In situ diagnostic of two-phase flow phenomena in polymer electrolyte fuel cells by neutron imaging: Part B. Material variations. Electrochimica Acta, 2006. 51(13): p. 2715-2727.

56. Ludlow, D.J., et al., PEM fuel cell membrane hydration measurement by neutron imaging. Journal of Power Sources, 2006. 162(1): p. 271-278.

57. Iranzo, A. and P. Boillat, Liquid water distribution patterns featuring back-diffusion transport in a PEM fuel cell with neutron imaging. International Journal of Hydrogen Energy, 2014. 39(30): p. 17240-17245.

58. Turhan, A., et al., Passive control of liquid water storage and distribution in a PEFC through flow-field design. Journal of Power Sources, 2008. 180(2): p. 773-783.

59. Hickner, M.A., et al., Real-time imaging of liquid water in an operating proton exchange membrane fuel cell. Journal of The Electrochemical Society, 2006. 153(5): p. A902.

60. Trabold, T.A., et al., In situ investigation of water transport in an operating PEM fuel cell using neutron radiography: Part 1 - Experimental method and serpentine flow field results. International Journal of Heat and Mass Transfer, 2006. 49(25): p. 4712-4720.

61. García-Salaberri, P.A., et al., Hydration and dehydration cycles in polymer electrolyte fuel cells operated with wet anode and dry cathode feed: A neutron imaging and modeling study. Journal of Power Sources, 2017. 359: p. 634-655.

62. Gößling, S., et al., Analysis of liquid water formation in polymer electrolyte membrane (PEM) fuel cell flow fields with a dry cathode supply. Journal of Power Sources, 2016. 306: p. 658-665.

63. Cho, J.I.S., et al., Visualization of liquid water in a lung-inspired flow-field based polymer electrolyte membrane fuel cell via neutron radiography. Energy, 2019. 170: p. 14-21.

64. Zhang, G., et al., Simultaneous measurement of current and temperature distributions in a proton exchange membrane fuel cell. Journal of Power Sources, 2010. 195(11): p. 3597-3604.

65. O'Hayre, R., et al., Fuel cell reaction kinetics, in Fuel cell fundamentals. 2006, John Wiley \& Sons. p. 59-92.

66. Benziger, J., et al., Reaction dynamics in a parallel flow channel PEM fuel cell. Journal of The Electrochemical Society, 2007. 154(8): p. B835.

67. Vie, P.J.S. and S. Kjelstrup, Thermal conductivities from temperature profiles in the polymer electrolyte fuel cell. Electrochimica Acta, 2004. 49(7): p. 1069-1077.

68. Lee, C.-Y., W.-J. Hsieh, and G.-W. Wu, Embedded flexible micro-sensors in MEA for measuring temperature and humidity in a micro-fuel cell. Journal of Power Sources, 2008. 181(2): p. 237-243.

69. Ramousse, J., et al., Modelling of heat, mass and charge transfer in a PEMFC single cell. Journal of Power Sources, 2005. 145(2): p. 416-427.

70. Weber, A.Z. and J. Newman, Coupled thermal and water management in polymer electrolyte fuel cells. Journal of The Electrochemical Society, 2006. 153(12): p. A2205.

71. Ramousse, J., et al., Local voltage degradations (drying and flooding) analysis through 3D stack thermal modeling. Journal of Fuel Cell Science and Technology, 2010. 7(4).

72. Strickland, D.G., S. Litster, and J.G. Santiago, Current distribution in polymer electrolyte membrane fuel cell with active water management. Journal of Power Sources, 2007. 174(1): p. 272-281.

73. Hartnig, C., et al., Combined neutron radiography and locally resolved current density measurements of operating PEM fuel cells. Journal of Power Sources, 2008. 176(2): p. 452-459.

74. Lin, R., et al., Investigation of membrane pinhole effects in polymer electrolyte fuel cells by locally resolved current density. Journal of The Electrochemical Society, 2011. 158(1): p. B11-B17. 